\title{
ANALISIS SEKTOR UNGGULAN DAN PERGESERAN STRUKTUR DALAM MENINGKATKAN PERTUMBUHAN EKONOMI NTB 2000-2015
}

\author{
Analysis of The Economic Basic Sectors and Structural Shifts In Order To Enhance \\ Economic Growth In West Nusa Tenggara (NTB) Province in the Period of 2000-2015
}

\author{
Yuni Purnama ${ }^{1}$, Muhammad Nurjihadi ${ }^{1}$, Fitriah Permata Cita ${ }^{1}$ \\ ${ }^{1}$ Program Studi Ekonomi Pembangunan, Fakultas Ekonomi dan Bisnis Universitas Teknologi Sumbawa
}

*)e-mail:purnama.yuni42@gmail.com

\begin{abstract}
The objectives of this study are: (1) to know the economic basic sectors in West Nusa Tenggara (NTB) province within 2000-2015; (2) to know the economical changing and shifts of NTB province within 2000-2015. The analysis tool that used to answers the first objective is Location Quotient (LQ) analysis, where the results will show the basic sectors that can be used for policy making and development planning in NTB province. Meanwhile, shift-share analysis is used to answer the second objective. This analysis wil show the economic structure and the changing pattern of sectoral growth in economy. The results showed that basic sectors in NTB province within 2000-2009 were: 1)Agriculture, animal husbandry, forestry, and fishery; 2) Mining and excavation; 3) Construction; 4) Transportation and communication; and 5) Services. Furthermore, the basic sectors for 2010-2015 were: 1) Agriculture, forestry and fishery; 2) Mining and Excavation; 3) Transportation and Wareshousing; 4) Public administration, defense and compulsory, social security; 6) Education Services; 7) Health services and others. On the other hand, based on shift share analysis, there was an economical structural shift in NTB province during 2000-2015 which is showed by the changing of each component value in the shift-share. Moreover, the province economy was influenced conciderably by national policies which is indicated by the high value of national share in the shift share analysis.
\end{abstract}

Key words: Location Quotient, shift-share, PDRB, economic growth

\begin{abstract}
ABSTRAK
Tujuan penelitian ini adalah : (1) Untuk mengetahui sektor unggulan dalam perekonomian Provinsi Nusa tenggara Barat (NTB)tahun 2000-2015, (2) Untuk mengetahui perubahan dan pergeseran sektor perekonomian Provinsi NTB tahun 2000-2015.Alat analisis yang digunakan untuk menjawab tujuan penelitian nomor satuadalah Location Quotient (LQ) dimana hasil analisis ini nantinya akan menunjukkan sektor-sektor unggulan yang dapat dijadikan sebagai pertimbangan dalam perumusan kebijakan dan perencanaan pembangunan di Provinsi NTB. Sedangkan untuk menjawab tujuan penelitian nomor dua digunakan alat analisis shift-share dimana hasil dari analisis ini akan menunjukkan struktur dan pola perubahan pertumbuhan sektoral dalam perekonomian.Hasil analisis menunnjukkan bahwa sektor unggulan di provinsi NTB tahun 2000-2009 adalah 1. pertanian, peternakan, kehutanan dan perikanan, 2. pertambangan dan penggalian, 3. bangunan, 4. pengangkutan dan komunikasi, 5. jasa - jasa, sedangkan untuk tahun 2010-2015 adalah 1. pertanian, kehutanan dan perikanan, 2. pertambangan dan penggalian, 3. transportasi dan pergudangan, 4. Administrasi pemerintahan, pertahanan dan jaminan sosial wajib, 5.Jasa pendidikan, 6.Jasa kesehatan dan kegiatan lainnya, dan 7.Jasa lainnya.Sementara itu berdasarkan Hasil analisis shift share menunjukkan bahwa selama tahun 2000-2015 telah terjadi pergeseran struktur perekonomian di Provinsi NTB yang ditunjukkan dengan berubahnya nilai dari masing-masing komponen shift-share. Selain itu, ekonomi di provinsi ini juga banyak dipengaruhi oleh kebijakan nasional yang ditunjukkan dengan besarnya nilai national share dalam analisis shift-share.
\end{abstract}

Kata Kunci: Location Quotient, shift-share, PDRB, pertumbuhan ekonomi.

\section{Pendahuluan}

Pembangunan ekonomi merupakan bagian penting dari pembangunan nasional dengan tujuan akhir meningkatkan kesejahteraan masyarakat, yang antara lain bisa diukur melalui pendapatan riil perkapita yang tinggi. Menurut Rostow dalam Jhingan (2014) ada lima tahap pertumbuhan ekonomi yaitu : (1) masyarakat 
tradisional, (2) prasyarat tinggal landas, (3) tinggal landas, (4) dewasa (maturity) dan (5) masa konsumsi massal. Salah satu indikator keberhasilan pembangunan ekonomi adalah tingkat pertumbuhan ekonomi, sehingga tidak heran jika setiap negara ataupun daerah senantiasa selalu memperhatikan laju pertumbuhan perekonomiannya termasuk Indonesia.

Pertumbuhan ekonomi dapat diartikan sebagai suatu kondisi dimana terjadi peningkatan pendapatan yang disebabkan oleh meningkatnya jumlah produksi barang dan jasa.Menurut Bhinadi (2003) Ada tiga macam ukuran untuk menilai pertumbuhan ekonomi yaitı pertumbuhan output, pertumbuhan output per pekı dan pertumbuhan output per kapita. Pertumbuhan output digunakan untuk menilai pertumbuhan kapasitas produksi yang dipengaruhi oleh adanya peningkatan tenaga kerja dan modal di wilayah tersebut. Pertumbuhan output per tenaga kerja sering digunakan sebagai indikator adanya perubahan daya saing wilayah tersebut (melalui pertumbuhan produktivitas). Sedangkan pertumbuhan output per kapita digunakan sebagai indikator perubahan kesejahteraan ekonomi. Beberapa strategi yang dilakukan oleh pemerintah yang memberikan dampak yang cukup bagus untuk pertumbuhan ekonomi adalah otonomi daerah.

Berdasarkan UU No 32 Tahun 2004 Pasal 1 angka 5 definisi otonomi daerah adalah hak, wewenang, dan kewajiban daerah otonom untuk mengatur dan mengurus sendiri urusan pemerintahan dan kepentingan masyarakat setempat sesuai dengan peraturan perundang-undangan. Adanya otonomi daerah ini tentunya memberikan kesempatan yang seluas-luasnya bagi pemerintah provinsi dan pemerintah kabupaten/kota diindonesia untuk mengatur dan mengelolah sumber daya yang dimiliki guna dimanfaatkan semaksimal mungkin sesusai dengan peraturan perundang-undangan. Adanya otonomi daerah ini tentunya akan mengurangi ketergantungan pemerintah daerah terhadap pemerintah pusat atau dengan kata lain akan membentuk pemerintah daerah yang lebih mandiri. Salah satu tantangan bagi pemerintah daerah dalam menjalankan kebijakan otonomi daerah adalah mengidentifikasi danmemahami potensi daerah yang dimiiki daerahnya. Pemerintah daerah yang sudah mengetahui potensi daerah yang dimiliki tentu akan lebih maksimal dalam memanfaatkan potensi tersebut untuk dijadikan sebagai sumber pendapatan daerah. Begitupun sebaliknya pemerintah yang belum mengetahui potensi yang dimiliki daerahnya tentu tidak akan maksimal dalam memanfaatkan potensi tersebut. Pemanfaatan potensi tersebut nantinya akan memudahkan pemerintah daerah untuk mengetahui sektor ekonomi yang pengembangannya perlu diprioritaskan yaitu sektor basis dibanding sektor lainnya atau sektor non basis.

Sektor ekonomi basis adalah sektor yang kinerja utamanya bergantung pada pengaruh kondisi ekonomi eksternal atau luar daerah terhadap perkonomian lokal untuk pembangunan ekonomi, sementara sektor non basis adalah sektor yang kinerja utamanya bergantung pada kondisi ekonomi internal regional itu sendiri dan terfokus pada persediaan untuk konsumsi lokal (Thomas et al, 1998). Bertambahnya kegiatan basis suatu daerah akan berpengaruh terhadap peningkatan arus pendapatan daerah tersebut, yang selanjutnya akan menambah permintaan barang dan jasa didaerah tersebut, yang kemudian akan berdampak terhadap tumbuhnya kegiatan non basis. Begitupun sebaliknya jika kegiatan basis berkurang maka akan berdampak pada berkurangnya pendapatan yang mengalir kedalam suatu daerah, sehingga akan mengakibatkan turunnya permintaan terhadap produk kegiatan non basis.

Adanya kegiatan sektor basis dan sektor non basis dalam pembangunan ekonomi secara tidak langsung akan membawa suatu perubahan mendasar dalam struktur ekonomi. Dari sektor ekonomi tradisional yang didominasi oleh kegiatan pertanian sebagai sektor primer menuju ekonomi modern yang didominasi oleh sektor sekunder dan tersier khususnya industri pengolahan, perdagangan dan jasa sebagai indikator utama penggerak ekonomi (Rostow dalam Jhingan, 2014). Menurut Todaro (2012) Teori perubahan struktur ekonomi menitik beratkan pada mekanisme transformasi ekonomi yang di alami oleh negara maupun pada daerah sedang berkembang yang semula bersifat subsisten dan menitik beratkan pada sektor pertanian menuju ke struktur ekonomi yang modern di dominasi oleh sektor industri dan jasa.

Struktur ekonomi digunakan untuk menunjukkan susunan-susunan ekonomi dalam suatu perekonomian. Sektor yang dominan atau memiliki konstribusi terbesar dalam struktur tersebut akan menjadi ciri khas dari suatu perekonomian. Ada dua teori utama yang umum digunakan dalam menganalisis perubahan struktur ekonomi, yakni dari Lewis (teori migrasi) dan Chenery (teori transformasi struktual). Teori perubahan struktual menitikberatkan pembahasan pada mekanisme transformasi ekonomi yang dialami oleh NSB, yang semula lebih bersifat subsistens dan menitikberatkan pada sektor pertanian menuju ke struktur perekonomian yang lebih modern, yang didominasi oleh sektor-sektor nonprimer (Tarigan 2014)

Provinsi Nusa Tenggara Barat (NTB) memiliki beragam potensi sumber daya yang siap untuk dikembangkan dan dikelolah sesuai dengan ketersediaan dan faktor-faktor 
yang dimiliki. Pemanfaatan sumber daya yang maksimal secara tidak langsung akan meningkatkan pertumbuhan ekonomi suatu daerah. Faktor penentu utama pertumbuhan ekonomi suatu daerah adalah berhubungan langsung dengan permintaan akan barang dan jasa dari luar daerah (Richardson, 2001). Selain itu Provinsi NTB juga merupakan salah satu provinsi di indonesia yang memiliki laju pertumbuhan ekonomi yang cukup tinggi dibanding pertumbuhan ekonomi nasional dimana pada triwulan II-2016 laju pertumbuhan ekonomi NTB tumbuh sebesar 9,92 persen (\%) sedangkan laju pertumbuhan nasional hanya 5,18 persen (BPS, 2016). Selama periode 2011-2015 pertumbuhan ekonomi NTB tidak bisa dikatakan stabil, pasalnya pada tahun 2011 laju pertumbuhan ekonomi NTB adalah -3,91\%, selanjutnya ditahun 2012 , naik menjadi $-1,54 \%$ dan terus naik menjadi 5,16\% ditahun 2013 kemudian ditahun 2014 turun menjadi 5.06\% dan naik secara signifikan pada tahun 2015 menjadi 21,24\%. Sektor yang memberikan konstribusi terbesar terhadap pertumbuhan ekonomi NTB tahun 2010 adalah sektor pertambangan dan penggalian yaitu sebesar $29,19 \%$, dan diikuti oleh sektor pertanian 21,30\%, kemudian ditahun 2011 terjadi perubahan dimana sektor yang paling besar konstribusinya terhadap PDRB adalah pertanian yaitu sebesar 23,29\%, yang selanjutnya diikuti oleh sektor pertambangan dengan nilai sebesar $21,83 \%$. Konstribusi terbesar sektor pertanian ini tidak hanya terjadi pada tahun 2011 tetapi juga pada tahun 2012 dengan nilai konstribusi sebesar 24,73\%, tahun 2013 24,28\% dan tahun 2014 sebesar 24,14\% (BPS, 2016). Meskipun konstribusi PDRB dari sektor pertanian tahun 2011 hingga 2014 menjadi penyumbang terbesar bagi PDRB provinsi NTB, namun laju pertumbuhan sektor pertanian terbilang rendah.

Provinsi NTB memerlukan perhatian khusus untuk memperbaiki kondisi tersebut karena dengan adanya konstribusi sektor yang dominan terhadap PDRB secara tidak langsung akan mempengaruhi struktur ekonomi. Untuk itu pemerintah perlu meninjau sektor ekonomi mana yang memiliki potensi untuk dijadikan sektor basis. Pembangunan sektor-sektor ekonomi dengan menganalisis sektor basis ekonomi provinsi NTB, sangat diperlukan yakni dengan mengetahui terlebih dahulu sektor unggulan untuk meningkatkan perekonomian wilayah. Kemungkinan terjadinya pergeseran struktur perekonomian provinsi NTB juga harus mendapatkan perhatian lebih dari pemerintah daerah. Hal tersebut penting dilakukan dijadikan sebagai dasar dalam perencanaan pembangunan ekonomiBerdasarkan uraian diatas maka latar belakang tujuan penelitian sebagai berikut:

1. Sektor-sektor manakah yang menjadi sektor unggulan dalam perekonomian Provinsi Nusa Tenggara Barat tahun 2000-2015?
2. Apakah struktur ekonomi Provinsi Nusa Tenggara Barat tahun 2000-2015 mengalami pergeseran?

\section{Pertumbuhan Ekonomi}

Teori pertumbuhan neoklasik diawali dengan asumsi sederhana yaitu tidak adanya perkembangan teknologi. Hal ini berimplikasi perekonomian akan mencapai tingkat output dengan modal jangka panjang yang disebut steady-state equilibrium. Steady-state equilibrium untuk sebuah perekonomian adalah kombinasi dari PDB per kapita dan modal per kapita dimana perekonomian akan stabil, yaitu, dimana tidak ada lagi variabel ekonomi perkapita yang berubah, $\Delta y=$ 0 dan $\Delta k=0$ (Dornbusc et al, 2008).

\section{Sektor Basis dan Non Basis}

Sektor basis (sektor unggulan) pada dasarnya selalu dikaitkan dalam bentuk perbandingan, baik itu perbandingan ditingkat regional, nasional maupun internasional. Dalam kaitannya dengan lingkup nasional suatu sektor dikatakan unggul jika sektor tersebut mampu bersaing dipasar domestik dengan sektor yang sama dari daerah lain. Menurut Tarigan (2009) Teori basis ekonomi pada dasarnya mengemukakan laju pertumbuhan ekonomi suatu wilayah ditentukan oleh besarnya peningkatan ekspor dari wilayah tersebut.

\section{Struktur Ekonomi}

Menurut Todaro (2012) tingkat perubahan struktural dan sektoral yang tinggi, berkaitan dengan proses pertumbuhan ekonomi. Beberapa komponen utama perubahan struktural tersebut mencakup "pergeseran" yang berangsurangsur dari aktifitas pertanian ke sektor non petanian dan dari sektor industri ke jasa. Salah satu ahli ekonomi aliran pendekatan struktur ini adalah Lewis dengan model teoritisnya tentang "Surplus tenaga kerja dua sektor".

\section{Metode Penelitian}

Jenis penelitian ini bersifat deskriptif kuantitatif. Metode deskriptif kuantitatif pada penelitian ini adalah untuk mengidentifikasi dan menganalisis potensi ekonomi dengan cara mengukur variabel-variabel ekonomi yang terkait berdasarkan pada PDRB sektoral. Hal ini dilakukan untuk mengetahui kecenderungan serta membuktikan secara matematis sederhana berbagai data yang bersifat kuantitatif.

Jenis data yang digunakan dalam penelitian ini adalah data sekunder. Data sekunder bisa diartikan sebagai data pendukung yang diperoleh dari buku-buku yang berkaitan dengan penelitian atau dengan mengambil dari sumber lain yang diterbitkan oleh lembaga yang dianggap kompeten berupa data PDRB NTB selama 15 tahun, data PDB Indonesia selama 15 tahun. 
Untuk menjawab rumusan masalah dan tujuan penelitian menggunakan analisis yaitu Location Quotien digunakan untuk menjawab rumusan masalah dan tujuan penelitian pada poin pertama, Shift Share analisis dan perhitungan bersih digunakan untuk menjawab rumusan masalah dan tujuan penelitian pada poin kedua.

Penjelasan tentang alat analisis yang digunakan adalah sebagai berikut:

\section{Analisis Location Quotient (LQ)}

Location Quotient atau biasa disingkat LQ adalah suatu perbandingan tentang besarnya peranan suatu sektor/industri disuatu daerah terhadap besarnya peranan sektor/industry tersebut secara nasional (Taringan, 2005). Hasil analisis ini digunakan untuk mengetahui sektor basis dan sektor non basis di kabupaten Sumbawa. Metode ini umum di gunakan dalam model ekonomi basis sebagai langkah awal untuk memahami sektor kegiatan dari PDRB Kabupaten Sumbawa yang menjadi pemacu pertumbuhan ekonomi.

Nilai LQ sering digunakan untuk menentukan sektor basis yang dapat digunakan sebagai sektor yang akan mendorong tumbuhnya sektor lain yang nantinya akan berdampak pada penciptaan tenaga kerja. Formula LQ dapat dirumuskan sebagai berikut:

$$
L Q=\frac{x i / P D R B i}{X i / P D B i}
$$

dimana:

$x i \quad$ :PDRB sektor $\mathrm{i}$ di Provinsi NTB pada tahun tertentu

PDRBi :Total PDRB di Provinsi NTB pada tahun tertentu

Xi :PDB sektor I di tingkat nasional pada tahun tertentu

PDBi :Total PDB di tingkat nasional pada tahun tertentu.

Berdasarkan formula diatas maka Kriteria pengujian LQ dapat dibagi kedalam 3 kelompok yaitu:Apabila nilai LQ>1, maka dapat disimpulkan bahwa sektor tersebut merupakan sektor basis dan potensial untuk dikembangkan sebagai penggerak perekonomian Provinsi NTB. Sebaliknya apabila nilai $\mathrm{LQ}<1$, maka sektor tersebut bukan merupakan sektor basis dan kurang potensial untuk dikembangkan sebagai penggerak perekonomian Provinsi NTB (Kuncoro, 2013).

\section{Analiis Shift Share}

Untuk menjawab rumusan masalah dan tujuan penelitian tentang pergeseran struktur ekonomi digunakan alat analisis shift share. Alat analisis ini membandingkan laju pertumbuhan berbagai sektor/industri di provinsi NTB dengan wilayah nasional. Hasil analisis ini nantinya akan memberikan gambaran tentang kinerja sektor-sektor dalam PDRB provinsi NTB dibandingkan dengan PDB Nasional. Langkah selanjutnya yaitu melakukan analisis terhadap penyimpangan yang terjadi sebagai hasil perbandingan tersebut. Bila penyimpangan tersebut positif, maka dikatakan suatu sektor dalam PDRB Provinsi NTB memiliki keunggulan kompetitif atau sebaliknya. Data yang diperlukan dalam analisis ini adalah PDRB Provinsi NTB dan PDB Nasional menurut lapangan usaha atas dasar harga konstan pada tahun tertentu.

Data yang digunakan dalam analisis shift share ini adalah data PDRB Provinsi NTB tahun 2010-2014 dan data PDB nasional tahun 2010-2014 menurut lapangan usaha atas dasar harga konstan tahun 2010. penggunaan data harga konstan dengan tahun dasar yang sama agar bobotnya (nilai riilnya) bisa sama dengan perbandingan menjadi valid (tarigan, 2005).

Pertumbuhan ekonomi dan pergeseran struktural perekonomian NTB dapat diketahui dengan mlihat 3 komponen analisis shift share berikut:

1. Propinsial Share (PS), digunakan untuk mengetahui pertumbuhan atau pergeseran struktur perekonomian Provinsi NTB dengan melihat PDB Nasional sebagai daerah pengamatan pada periode awal yang dipengaruhi oleh pergeseran pertumbuhan perekonomian nasional. Provincial Share akan menggambarkan peranan ekonomi nasional yang mempengaruhi pertumbuhan perekonomian Provinsi NTB.

2. Proportional Shift (P), atau dikenal sebagai komponen struktural atau industrial mix, mengukur besarnya shift regional netto yang diakibatkan oleh komposisi sektor-sektor industri di daerah yang bersangkutan. Proportional shift adalah akibat dari unsur-unsur luar yang bekerja secara nasional.

3. Differential shift (DS), Komponen ini mengukur besarnya shift regional netto yang diakibatkan oleh sektor-sektor industri tertentu yang tumbuh lebih cepatatau lebih lambat di daerah yang bersangkutan daripada tingkat nasionalyang disebabkan oleh faktorfaktor lakasional intern. Differential shift adalah akibat dari pengaruh faktor-faktor yang bekerjakhusus di daerah yang bersangkutan (Taringan, 2005).

Menurut Soepomo dalam Novita, bentuk umum persamaan analisis shift share adalah:

$$
\begin{array}{ll}
D_{i j} & =N_{i j}+M_{i j}+C_{i j} \\
N_{i j} & =y_{i j} \cdot r n \\
M_{i j} & =M_{i j}\left(r_{i n}-r n\right)
\end{array}
$$




$$
\mathrm{C}_{\mathrm{ij}} \quad=\mathrm{y}_{\mathrm{ij}}\left(\mathrm{r}_{\mathrm{ij}} \mathrm{r}_{\mathrm{in}}\right)
$$

Keterangan:

I : Sektor-sektor ekonomi yang diteliti

J : Variabel wilayah yang diteliti (Provinsi NTB)

Dij : Perubahan sektor i di daerah j (Provinsi NTB)

Nij : Pertumbuhan sektor i di daerah j (Provinsi NTB)

Mij : Bauran industri sektor i di daerah j (Provinsi NTB)

Cij : Keunggulan kompetitif sektor i di daerah $\mathrm{j}$

Eij : PDRB sektor i di daerah j (Provinsi NTB)

Rij : Rata-rata laju pertumbuhan sektor i di daerah $\mathrm{j}$

Rin : laju pertumbuhan sektor $\mathrm{i}$ di daerah $\mathrm{n}$ (Nasional)

Rn : laju pertumbuhan PDB di daerah n (Nasional)

Masing-masing pertumbuhan dapat didefinisikan sebagai berikut:

$$
R i j=\left(e^{*} i j-e i j\right) / e i j .
$$

Untuk mengukur laju pertumbuhan sektor i di wilayah j.

$$
\operatorname{Rin}=\left(e^{* i n-e i n}\right) / \text { ein. }
$$

Untuk mengukur laju pertumbuhan sektor i perekonomian Nasional.

$$
R n=\left(e^{*} n-e n\right) / e n .
$$

Untuk mengukur laju pertumbuhan Nasional.

Keterangan:

e*in : PDRB sektor i di tingkat nasional pada tahun akhir analisis.

ein : PDRB sektor i ditingkat nasional pada tahun dasar tertentu.

$\mathrm{e}^{* \mathrm{ij}} \quad$ : PDRB sektor $\mathrm{i}$ di wilayah $\mathrm{j}$ pada tahun akhir analisis.

eij : PDRB sektor i di wilayah $\mathrm{j}$ pada tahun dasar tertentu.

e*n : PDRB nasional pada tahun akhir analisis.

en : PDRB nasional pada tahun dasar tertentu.

\section{Hasil Analisis LQ (Location Quotient)}

Berdasarkan hasil analisis dengan menggunakan metode LQ (Location Quotient) di Provinsi NTB dapat diketahui bahwa terdapat 5 sektor basis yang memiliki keunggulan komparatif atau yang memiliki nilai LQ $>1$, diantaranya: 1. pertanian, peternakan, kehutanan dan perikanan, 2. pertambangan dan penggalian, 3 . bangunan, 4. pengangkutan dan komunikasi, dan 5. jasa - jasa. Sedangkan empat sektor lain merupakan sektor non basis karena memiliki nilai $\mathrm{LQ}<1$ diantaranya: industri pengolahan dengan nilai rata-rata LQ 0,16 sektor listrik, gas dan air bersih dengan nilai rata-rata LQ
0,45 kemudian sektor keuangan, persewaan dan jasa perusahaan dengan nilai rata-rata LQ 0,47 dan sektor perdagangan, hotel dan restoran dengan nilai rata-rata LQ 0,85.Tingginya konstribusi sektor pertanian dan pertambangan sebagai sektor primer menunjukan bahwa srtuktur ekonomi NTB adalah strukturagraris yaitu struktur ekonomi yang didominasi oleh sektor pertanian dan pertambangan sebagai mata pencaharian utama masyarakatnya.Terkait kondisi tersebut maka provinsi NTB masih tergolong ke dalam sektor tahap masyarakat tradisional dimana menurut Rostow dalam masyarakat tradisional ini produksi perkapita masih sangat terbatas dan sumber daya produksi utama adalah sektor pertanian, sehingga sangat kecil kemungkinan untuk mengadakan mobilitas vertikal dikarenakan kedudukan masayarakat tidak akan jauh berbeda dengan kedudukan ayahnya dan sistem mobilitasnya umumnya berdasarkan sistem warisan (pemeberian).

Terdapat perbedaan sektor yang menyusun PDRB sebelumnya yang menggunakan tahun dasar 2000 dan dengan yang menggunakan tahun dasar 2010. Pada tahun dasar 2000 terdapat Sembilan sektor penyusun PDRB, sementara pada tahun dasar 2010 terdapat 17 sektor penyusun PDRB. Salah satu alasan penambahan sektor ini adalah banyak perubahan yang terjadi pada tatanan global dan lokal yang sangat berpengaruh pada perekonomian nasional. Krisis finansial global atau penerapan perdagangan bebas merupakan contoh perubahan yang perlu diadaptasi dalam mekanisme pencatatan statistik nasional. Salah satu bentuk adaptasinya adalah mengubah tahun dasar PDB Indonesia dari tahun 2000 ke 2010. (BPS, 2017).

Dari hasil analisis LQ Provinsi NTB atas dasar harga konstan tahun 2010 terdapat 7 sektor basis yang memiliki keunggulan komparatif atau yang memiliki nilai $L Q>1$, yaitu: 1. Sektor pertanian, kehutanan \& perikanan 2. Sektor pertambangan \& penggalian 3.Sektor transportasi dan pergudangan 4. Sektor administrasi pemerintahan, pertahanan dan 5.Sektor jasa pendidikan 6.Sektor jasa kesehatan dan kegiatan lainnya 7. Sektor jasa lainnya. Dari ketujuh sektor basis tersebut yang memiliki nilai LQ tertinggi adalah sektor pertambangan \& penggalian dengan nilai LQ 2,15 yang kedua adalah sektor jasa kesehatan dan kegiatan lainnya dengan nilai LQ 1,86 yang ketiga adalah sektor transportasi dan pergudangan dengan nilai LQ 1,80 dan yang keempat adalah sektor pertanian, kehutanan \& perikanan dengan nilai LQ 1,72 diikuti oleh ketiga sektor basis lainnya.

Tingginya nilai LQ Sektor pertambangan \& penggalian di Provinsi NTB dari tahun 2000-2015 menunjukkan bahwa sektor ini memberikan konstribusi yang besar terhadap pembentukan PDRB. Hal ini disebabkan oleh 
Undang-Undang No 33 Tahun 2004 pasal 14 (3) hasil dari penerimaan pertambangan umum yang dihasilkan dari wilayah yang bersangkutan, dibagi dengan imbang $20 \%$ (dua puluh persen) untuk pemerintah dan $80 \%$ (delapan puluh persen) untuk daerah.

Sedangkan sepuluh sektor lain termasuk kedalam sektor non basis karena memiliki nilai $\mathrm{LQ}<1$, kesepuluh sektor tersebut diantaranya adalah 1 . sektorindustri pengolahan 2. pengadaan listrik dan gas 3 . pengadaan air, pengelolaan sampah, limbah dan daur ulang 4 . konstruksi 5. perdagangan besar dan eceran, reparasi mobil dan motor 6. penyediaan akomodasi dan makan minum 7. informasi dan komunikasi 8. jasa keuangan dan asuransi 9. real estate 10 . jasa perusahaan.

\section{Hasil Analisis Shift-Share}

Alat analisis yang digunakan untuk mengetahui pergeseran struktur ekonomi adalah analisis shift shareklasik. Dari analisis shift-share akan terlihat kinerja sektor-sektor dalam PDRB di Provinsi NTB dibandingkan sektor PDB nasional.

Hasil analisis shift-share klasik menunjukkan bahwa selama tahun analisis 2000-2004 dengan tahun dasar 2000 nilai PDRB sektoral Provinsi NTB telah mengalami perubahan dimana pada tahun 2000 nilai PDRB sektoral adalah sebesar Rp 234.019.599,43 dan turun menjadi Rp 215.574.480.61 pada tahun 2004 . Perubahan ini dipengaruhi oleh komponen pertumbuhan nasional (Nij), Bauran Industri (Mij) dan Keunggulan Kompetitif (Cij).

Berdasarkan hasil perhitungan komponen pertumbuhan nasional (Nij), pertumbuhan ekonomi Nasional telah mempengaruhi pertumbuhan ekonomi Provinsi NTB sebesar Rp 234.019.599,43. Nilai Nij yang positif menunjukkan bahwa kebijakan umum secara nasional berpengaruh positif terhadap pertumbuhan sektor PDRB di Provinsi NTB.Salah satu kebijakan tersebut misalnya adalah tingkat inflasi dan subsidi.

Komponen bauran industri atau (Mij) menyatakan seberapa besar perubahan perekonomian wilayah sebagai akibat adanya bauran industri. Hasil analisis menunjukkan bahwa bauran industri memberikan pengaruh yang negatif terhadap perkembangan perekonomian Provinsi NTB, yaitu sebesar Rp 57.984.599,39. Dari tabel diatas kita dapat melihat sektor-sektor yang memiliki pengaruh negatif dari komponen bauran industri yaitu: a. pertanian, peternakan, kehutanan dan perikanan b. pertambangan dan penggalian dan c. keuangan, persewaan dan jasa perusahaan. Sedangkan keenam sektor lain yang tergolong positif yaitu: 1. industri pengolahan 2. listrik, gas, dan air bersih 3 . bangunan 4 . perdagangan, hotel dan restoran 5. pengangkutan dan komunikasi 7 . keuangan, persewaan \& jasa perusahaan. Nilai positif pada komponen bauran industri menunjukkan bahwa sektor-sektor tersebut mampu tumbuh cepat dibanding sektor yang sama pada tingat nasional.

Hasil perhitungan komponen keunggulan kompetitif (Cij) pada tabel diatas adalah sebesar 39.539.480,57. Hal ini menunjukkan bahwa besarnya keunggulan kompetitif yang dimiliki akan memberikan dampak positif terhadap perekonomian Provinsi NTB. Terdapat lima sektor yang memiliki keunggulan kompetitif positif yaitu, pertambangan dan penggalian, industri pengolahan, listrik, gas, dan air bersih, perdagangan, hotel dan restoran, keuangan, persewaan \& jasa persh. Sektor-sektor tersebut merupakan sektor yang tumbuh cepat dibanding sektor yang sama ditingkat nasional. Salah satu faktor yang mempengaruhi keunggulan sektor tersebut adalah potensi sumber daya alam yang dimiliki. Menurut Ricardian sumber daya alam adalah mesin pertumbuhan (engine of growth) yang mentransformasikan sumber daya alam ke dalam "manmade capital" yang pada gilirannya akan menghasilkan produktivitas yang lebih tinggi di masa yang akan datang.

Sedangkan sektor yang tidak memiliki keunggulan kompetitif atau yang tumbuh lambat dibanding sektor yang sama ditingkat nasional adalah sektor 1. pertanian, peternakan, kehutanan dan perikanan, 2. bangunan, 3 . pengangkutan dan komunikasi, 4. jasa-jasa. Rendahnya keunggulan kompetitif yang dimiliki sektor tersebut dipengaruhi oleh produktivitas tenaga kerja di provinsi NTB yang terbilang masih rendah (BI,2014).

Secara keseluruhan dampak nyata pertumbuhan ekonomi (Dij) selama periode tahun 2000-2004 memiliki nilai yang positif. Hal ini memberikan indikasi bahwa keseluruhan sektor tergolong progresif.

Hasil analisis shift-share periode 2005-2009 dengan harga dasar kosntan 2000 menunjukan bahwa PDRB sektoral Provinsi NTB juga mengalami perubahan dari dari Rp 371.209.716,48 pada tahun 2005 menjadi $290.061 .888,26$ pada tahun 2009. Hal tersebut tentunya dipengaruhi oleh komponen pertumbuhan nasional (Nij), Bauran industri (Mij) dan keunggulan kompetitif (Cij).

Hasil perhitungan komponen pertumbuhan nasional (Nij), menunjukkan bahwa pertumbuhan ekonomi Nasional telah mempengaruhi pertumbuhan ekonomi Provinsi NTB sebesar Rp 371.209.716 Nilai positif menunjukkan bahwa perekonomian Provinsi NTB masih sangat bergantung pada perekonomian Nasional, sama seperti periode 5 tahun sebelumnya yang berarti 
bahwa program kebijakan umum yang diterapkan pemerintah memiliki pengaruh yang positif.

Hasil analisis (Mij) menunjukkan bahwa bauran industri memberikan pengaruh yang negatif terhadap perkembangan perekonomian Provinsi NTB, yaitu sebesar Rp -21.190.751,74 Nilai tersebut menunjukkan bahwa komposisi sektoral pada PDRB Provinsi NTB cenderung mengarah pada perekonomian yang pertumbuhannya lambat. Hasil perhitungan tersebut menunjukkan bahwa selama periode 2000-2009 terdapat penurunan pengaruh dari bauran industri dimana pada tahun 2000-2004 pengaruh bauran industri (Mij) adalah sebesar Rp -57.984.599,39 kemudian pada tahun 20052009 angka tersebut turun menjadi Rp -21.190.751,74. Selain itu juga terdapat perubahan sektor yang memberikan pengaruh negatif, dimana pada tahun 20002004 yang memberikan pengaruh negatif adalah sektor pertanian, peternakan, kehutanan dan perikanan, pertambangan dan penggalian dan keuangan, persewaan dan jasa perusahaan.Sedangkan pada tahun 2005-2009 yang memberikan pengaruh negatif pada komponen bauran industri (Mij) adalah sektor pertanian, peternakan, kehutanan dan perikanan, pertambangan dan penggalian dan sektor industri pengolahan.

Selain komponen bauran industri, komponen keunggulan kompetirif (Cij) juga mengalami perubahan. Dimana pada periode 2000-2004 nilai komponen keunggulan kompetitif (Cij) adalah sebesar 39.539.480,57 turunmenjadi-59.957.076,48 pada tahun 2005-2009. sektor yang memberikan pengaruh yang negatif pada periode ini adalah sektor pertanian, peternakan, kehutanan dan perikanan, pertambangan dan penggalian, pengangkutan dan komunikasi dan jasajasa. Nilai perhitungan yang negatif menunjukkan bahwa sedikit keunggulan kompetitif yang dimiliki dan memiliki daya saing yang rendah yang akan memberikan pengaruh negatif terhadap perkembangan perekonomian Provinsi NTB.

Dampak nyata pertumbuhan ekonomi (Dij) menunjukkan bahwa kesembilan sektor tersebut mempunyai prospek yang baik untuk mendorong pertumbuhan ekonomi.

Hasil perhitungan analisis shift-share pada periode 2010-2015 atas dasar harga konstan 2010, tidak jauh betbeda dengan hasil analisi shift-share pada periode 2005-2009 atas dasar harga konstan 2000. Dimana nilai keunggulan kompetitif (Cij) dan komponen bauran industri (Mij) tetap bernilai negatif. Berdasarkan analisis shift-share 2010-2015 nilai PDRB sektoral Provinsi NTB telah mengalami perubahan nilai PDRB, dimana pada tahun 2010 nilai PDRB adalah sebesar 2.164.096.362,27 pada tahun 2010 menjadi 1.432.069.140,00 pada tahun 2015. Terjadinya perubahan tersebut tentunya dipengaruhi oleh Komponen Pertumbuhan Nasional (Nij), Bauran Industri (Mij) dan Keunggulan Kompetitif. Komponen pertumbuhan (Nij) dalam hal ini pertumbuhan ekonomi Nasional telah mempengaruhi pertumbuhan ekonomi NTB sebesar Rp 2.164.096.362,27. Nilai positif menunjukkan bahwa perekonomian Provinsi NTB masih sangat bergantung terhadap perekonomian nasional.

Untuk komponen bauran industri hasil analisis memberikan gambaran bahwa bauran industri memberikan pengaruh yang negatif terhadap perkembangan perekonomian Provinsi NTB , yaitu sebesar Rp $-442.332 .916,17$ nilai tersebut menggambarkan bahwa komposisi sektoral pada PDRB Provinsi NTB mengarah pada perekonomian yang pertumbuhannya lambat. Hal tersebut menunjukkan bahwa selama periode 2000-2015 pengaruh bauran industri terhadap Provinsi NTB tidak bagus dikarenakan memberikan dampak yang negatif terhadap perkembangan pertumbuhan.

Nilai untuk komponen keunggulan kompetitif (Cij) selama periode 2010-2015 adalah sebesar Rp 289.694.306,10 sama halnya dengan komponen keunngulan kompetitif (Cij) pada tahun 2000-2009 yang bernilai negatif. Nilai negatif ini mengindikasikan bahwa sedikitnya keunggulan kompetitif yang dimiliki akan memberikan dampak negatif terhadap perkembangan perekonomian Provinsi NTB. Dari 17 sektor penyusun PDRB terdapat tujuh sektor yang bernilai negatif dan 10 sektor yang bernilai positif.Salah satu sektor bernilai negatif tersebut adalah sektor pertanian, kehutanan dan perikanan.Ke sepuluh sektor bernilai positif tersebut memiliki potensi untuk dikembangkan dalam memacu pertumbuhan ekonomi Provinsi NTB.

Dampak nyata pertumbuhan ekonomi (Dij) menunjukkan bahwa semua sektor PDRB Provinsi NTB bernilai Positif, hal ini berarti bahwa semua sektor tersebut memiliki prospek yang bagus untuk mendorong pertumbuhan ekonomi provinsi NTB.

Dari hasil analisis diatas dapat diketuhui bahwa telah terjadi pergeseran struktur perekokonomian dari sektor primer ke sektor non primer walaupun pergeseran tersebut masih relatif kecil.Hal ini dapat dilihat dari mulai menurunnya peran sektor pertanian dan mulai meningkatnya peran sektor non primer seperti sektor Transportasi dan pergudangan, sektor jasa kesehatan dan kegiatan lainnya.

\section{Kesimpulan}

1. Dari hasil analisis diketahui bahwa sektor basis di Provinsi NTB selama periode 2000-2009 adalah: 1 . sektor pertanian, peternakan, kehutanan dan perikanan, 2. pertambangan dan penggalian, 3. Sektor 
bangunan, 4. Sektor pengangkutan dan komunikasi 5. sektor jasa-jasa. Sedangkan sektor yang tergolong non basis adalah: 1. sektor industry pengolahan, 2. Sektor listrik, gas dan air bersih, 3. Sektor perdagangan hotel dan restoran, 4. Sektor keuangan, persewaan dan jasa perusahaan.

2. Hasil analisis sektor basis di provinsi NTB selama periode 2010-2015 adalah: 1. Sektor pertanian, kehutanan dan perikanan, 2. Sektor pertambangan dan penggalian, 3. Sektor transportasi dan pergudangan, 4. Sektor administrasi pemerintahan, pertahanan dan jaminan social wajib, 5. Sektor jasa pendidikan, 6 . Sektor kesehatan dan kegiatan lainnya, 7. Sektor jasa lainnya. Sedangkan untuk sektor non basis periode 2010-2015 adalah: 1. Sektor industry pengolahan, 2. Sektor pengadaan listrik dan gas, 3. Sektor pengadaan air, pengolahan sampah, limbah dan daur ulang, 4 . Sektor Konstruksi, 5. Sektor perdagangan besar dan eceran, reparasi mobil dan motor, 6. Penyediaan akomodasi dan makan minum, 7. Sektor informasi dan komunikasi, 8. Sektor jasa keuangan dan asuransi, 9. Sektor jasa real estate, 10. Sektor jasa perusahaan.

3. Analisis shift share dapat memberikan gambaran pergeseran dan peranan sektor perekonomian di Provinsi NTB. Pertumbuhan ekonomi di Provinsi NTB lebih banyak dipengaruhi oleh pertumbuhan nasional. Hal ini mencerminkan sektor perekonomia di Provinsi NTB sangat bergantung pada kebijakan nasional. Pertumbuhan beberapa sektor perekonomian di Provinsi NTB termasuk lambat, sehingga masih membutuhkan dukungan kebijakan pengembangan lebih lanjut.

\section{Saran}

1. Hasil identifikasi sektor-sektor yang memiliki pertumbuhan yang positif dapat ditindak lanjuti oleh pemerintah. Dengan demikian hal ini bisa membantu pemerintah daerah melihat kekuatan atau kelemahan wilayahnya dibandingkan dengan wilayah yang lain. Potensi-potensi yang positif dapat digunakan dalam strategi pengembangan wilayah.

2. Pemerintah Daerah hendaknya memprioritaskan pengembangan sektor yang menjadi basis serta mempunyai pertumbuhan cepat dan berdaya saing tinggi. Selain itu program kebijakan yang dibuat hendaknya tidak hanya memperioritaskan sektor yang sudah unggul saja melainkan perlu memberi perhatian terhadap sektor yang masih nonbasis sehingga dapat meningkat dan dapat mencukupi kebutuhan Provinsi NTB.

\section{Daftar Pustaka}

Aaron Ecel, et al.2011.Uganda's Comparative Agricultural Export Performance: A Shift-Share Analysis Approach"

Abidin, Zainal. 2015. Aplikasi Analisis Shift Share Pada Transformasi Sektor Pertanian Dalam Perekonomian Wilayah Di Sulawesi Tenggara

Adisasmita, Raharjo.2008. Pengembangan Wilayah: Konsep Dan Teori. Yogyakarta: Graha Ilmu.

Arsyad, lincolin, 2005.Pengantar Perencanaan Pembangunan Ekonomi Daerah.Yogyakarta : BPFE

Badan Pusat Statistik (BPS). Statistika Indonesia. Tahun 2000-2015

Badan Pusat Statistik Provinsi NTB (BPS). Indonesia Dalam Angka. Tahun 2000 - 2015

Hasani, Akrom. 2010. Analisis Struktur Perekonomian Berdasarkan Pendekatan Shift Share di Provinsi Jawa Tengah Periode Tahun 2003 - 2008. Skripsi. Fakultas Ekonomi Universitas Diponegoro: Semarang.

Herath, Janaranjana. 2008. Maumbe1 “A Dynamic Shift Share Analysis of Economic Growth in West Virginia"

James A. Brox, et al. A Demographically Augmented Shift-Share Employment Analysis: An Application to Canadian Employment Patterns

Janaranjana Herath at al. "A Dynamic Shift Share Analysis of Economic Growth in West Virginia"

Jhingan, M.L.2014.Ekonomi Pembangunan dan Perencanaan. Cetakan k Jakarta: Rajawali Pers

Kochanowsk,et el.The Shift-Share Methodology Deficiencies And Proposed Remedies

Ma'mun, Deddy., Sonny Irwansyah.2013.Analisis Pergeseran Struktur Ekonomi Dan Identifikasi SektorPotensial Wilayah Pengembangan(Studi Kasus Di Kabupaten Bekasi, Provinsi Jawa Barat).Jurnal Social Economic Of Agriculture, Volume 2, Nomor 1, Hlm 7-28

Nazir, M.2011. Metode Penelitian. Jakarta: Ghalia Indonesia

Prasetyo Soepono. 1993 "analisis shifeshare;Perkembangan dan Penerapan.Jurnal Ekonomi danBisnis Indonesia Vol 16.no 1

Richardson, Harry W. Dasar-Dasar Ilmu Ekonomi Regional, Terjemahan PaulSitohang Edisi Revisi. Jakarta : FE UI, 2001.

Riswan, Hasbiullah.2013.Analisis Sektor Basis Dan Pergeseran Struktur Perekonomian Kabupaten Sinjai 
Roger J. Beck. Employment Linkages From A Modified Shift -ShareAnalysis: An Illinois Example

Rompas, et al.2015. Potensi Sektor Pertanian Dan Pengaruhnya Terhadap Penyerapan Tenaga Kerja Di Kabupaten Minahasa Selatan. Volume 15 No. 04 Tahun 2015

Sangadji, Etta Mamang dan Sopiah. 2010. Perilaku Metodologi penelitian: pendekatan praktis dalam penelitian. Yogyakarta: Andi

Sirojuzilam, 2008.Disparitas Ekonomi dan Perencanaan Regional, KetimpanganEkonomi
Wilayah Barat dan Timur Propinsi Sumatera Utara.Pustaka Bangsa Press.

Sjafrizal, 2008.Ekonomi Regional, Teori dan Aplikasi. Padang: Baduose Media

Sukirno, Sadono. 2013. Makro Ekonomi. Teori Pengantar. Edisi Ketiga. Jakarta: PT Rajawali Pers

Taringan, Robinson, 2009. Ekonomi Regional Teori dan Aplikasi Revisi. Jakarta: PT Bumi Aksara.

Todaro, P Michael dan Smith, C Stephen.2003. Pembangunan Ekonomi Di Dunia Ketiga.Jakarta : Erlangga, 